Arch. Tierz., Dummerstorf 43 (2000) 3, 207-212 'Research Institute for the Biology of Farm Animals, Dummerstorf, Germany;
'State Institute of Agriculture and Fishery Mecklenburg-Vorpommern, Institute of Animal Production, Dummerstorf,
Germany

GUDRUN A. BROCKMANN', JÖRG MARTIN ${ }^{2}$, FRIEDRICH TEUSCHER' ${ }^{1}$ and MANFRED SCHWERIN ${ }^{1}$

\title{
Marker controlled inheritance of the polled locus in Simmental cattle
}

Dedicated to Professor Dr. D. Simon on the occasion of his $70^{\text {th }}$ birthday

\begin{abstract}
Summary
The inheritance of the polled phenotype in Simmental cattle was tested for linkage with alleles of four microsatellite markers on the proximal region of BTAI. For the study half-sib offspring of three sires were selected which are known to be heterozygous for the polled condition. The analysis of 57 animals ( 42 polled and 15 horned) revealed complete linkage between the polled locus and the markers BM6438 and SODIMicro2. The reliability of the prediction of the horn status of the offspring for marker assisted selection was estimated from its marker genotype in comparison to the paternal haplotype phases responsible for polledness, and from the allele frequencies of the favoured marker alleles in the random population.
\end{abstract}

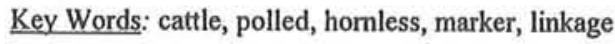

\section{Zusammenfassung}

Titel der Arbeit: Marker-vermittelte Kontrolle der Vererbung der Hornlosigkeit beim Fleckvieh

Mittels Kopplungsanalyse wurde beim Fleckvieh die gekoppelte Vererbung der Hornlosigkeit mit den Allelen von vier Markern in der proximalen Region des Chromosoms 1 des Rind untersucht. Fur die Analyse wurden Halbgeschwister von drei Bullen mit bekanntem heterozygotem Hornstatus genutzt. Alle 57 Tiere (42 hornlose und 15 gehörnte) zeigten vollstăndige Kopplung zu den Markern BM6438 und SODIMicro2. Für die markergestutzte Selektion wurde die Zuverlässigkeit der Vorhersage des Hornstatus der Nachkommen eines Bullen anhand ihrer Markergenotypen im Vergleich zur elterlichen Haplotypenphase, die für die Vererbung der Hornlosigkeit verantwortlich ist, und aus den Allelefrequenzen der mit der Hornlosigkeit gekoppelten Markerallele in der Population bestimmt.

Schlusselwörter: Rind, Hörner, Hornlosigkeit, Marker, Kopplung

\section{Introduction}

Selection for polled cattle became important for modern management of cattle in free stall barn. Polled cattle reduce the risk of injury by horns to animal breeders and prevent bruising of carcass and damages of the skin of the animals. The generation of homozygous polled breeds decreases cost and time for dehorning and eliminates the stress to animals. Much effort has been undertaken to generate a small population of pure bred polled Simmental cattle by traditional phenotype selection during the last 25 years (KRÄUßLICH and RÖHRMOSER, 1995). The selection of homozygous polled animals is required for efficient introgression programs. Thus, the marker assisted control of the polled inheritance is desirable. 
The inheritance of the horn formation in Bos taurus is determined by at least two mutations: one mutation in the major gene for polledness, which is responsible either for development of horns which are fused to the frontal bone or completely absent, and a second mutation which is responsible for the scurred phenotype. If the polled mutation and the scurred mutation are present, male animals develop scurs which are not fixed at the frontal bone and females are polled or scurred depending on whether the scurred locus is heterozygous or homozygous (LONG and GREGORY, 1978). The inheritance of the mutant allele at the polled locus is autosomal dominant. Therefore, the discrimination between homozygous and heterozygous polled animals is necessary for efficient animal breeding of polled animals.

Since the major gene responsible for horn formation has been mapped to the proximal region of Bos taurus chromosome BTAl near the Sodl gene by GEORGES et al., (1993), the location was verified in Charolais cattle by SCHMUTZ et al., (1995), in a cross of_Bos indicus x Bos taurus by BRENNEMAN et al., (1996), and in Simmental and_Pinzgauer cattle by HARLIZIUS et al., (1997).

The aim of our analyses was the mapping of the polled locus in a Simmental meat cattle population to determine linkage phases of alleles of closely linked markers with the polled mutation in the major gene for its use in marker assisted selection for pure bred polled cattle herds. Additionally, the animal panel used in this study would allow a better fine mapping of the polled locus as a prerequisite for the isolation of the underlying gene itself in a joint analysis with different published pedigrees.

\section{Methods}

Three paternal half-sib families as shown in Table 1 were collected representing Simmental. The founder sires were heterozygous $(\mathrm{Pp})$ polled animals mated to horned (pp) dams. The polled founder sires was descending from a cross between a homozygous polled bull with a horned dam. A total of 57 offspring was analysed with 42 polled versus 15 horned animals (additional horned animals were sold before collecting blood). Horn development was evaluated by observation and palpating at the age of one year. Among the offspring of sire P animals with horn buds were found. These animals were excluded from the analysis to prevent false phenotyping. The markers BM6438, BMS4015, BMS4017 (KAPPES et al., 1997; SONSTEGARD et al., 1997), SOD1Micro2 (MARQUESS et al., 1997) were informative in our pedigrees. The markers AGLA17, TGLA49, INRA117 and RM95 (TAYLOR et al., 1998) were tested, but were not polymorph for our bulls. BM6438 and SOD1Micro2 are known to be closely linked with the polled locus (GEORGES et al., 1993, HARLIZIUS et al.,

Table 1

Family structures (Struktur der Familien)

\begin{tabular}{lllll}
\hline Sire & Horn status & $\begin{array}{l}\text { Offspring } \\
\text { Total }(\text { Males; Females) }\end{array}$ & Polled $(\mathrm{P} / \mathrm{p})$ & Horned $(\mathrm{p} / \mathrm{p})^{*}$ \\
\hline $\mathrm{P}$ & $\mathrm{P} / \mathrm{p}$ & $42(20 ; 22)$ & 30 & 12 \\
$\mathrm{He}$ & $\mathrm{P} / \mathrm{p}$ & $10(10 ; 0)$ & 7 & 3 \\
$\mathrm{Ho}$ & $\mathrm{P} / \mathrm{p}$ & $5(5 ; 0)$ & 5 & 0 \\
total & & $57(35 ; 22)$ & 42 & 15 \\
\hline $\begin{array}{l}\text { The number of homed animals in comparison to polled animals is reduced because additional horned animals were sold before collection of } \\
\text { blood. }\end{array}$
\end{tabular}


1997). BMS4015 and BMS4017 are 27 and $33 \mathrm{cM}$ distal of the polled locus according to the genetic map of BTA1 (KAPPES et al., 1997).

For two-point linkage analyses between paternal marker alleles and the horn development of the offspring the statistical package CRIMAP was applied.

For the detection of frequencies of the marker alleles in Simmental breed the horned dams of the offspring were used as a representative sample.

\section{Results}

The two-point linkage tests proved the marker allele that was linked to the polled mutation and gave the recombination rates as a measure of the genetic distance between the marker and the polled locus. Table 2 gives the LOD-scores of the most likely distance between marker and polled mutation (Table 2). No recombination was detected in the analysed pedigrees between the polled gene and the markers SOD1Micro2 and BM6438. Furthermore, all three sires showed the same alleles which were linked with the polled mutation at these two markers. The genetic distances between the polled locus and markers BMS4015 and BMS4017 were estimated at 16.6 and $20.2 \mathrm{cM}$, underlying Kosambi Map function according to recombination rates of 0.16 and 0.19 , respectively.

Table 2

LOD scores for linkage of informative markers and the polled mutation (LOD-Scores fur die Kopplung zwischen informativen Markern und der Mutation fur Hornlosigkeit)

\begin{tabular}{|c|c|c|c|c|c|c|c|c|c|c|}
\hline \multirow[b]{2}{*}{ Marker } & \multirow[b]{2}{*}{ Family } & \multicolumn{6}{|c|}{ Recombination fraction } & \multicolumn{3}{|c|}{ Total } \\
\hline & & 0.00 & 0.05 & 0.10 & 0.15 & 0.20 & 0.25 & 0.30 & $\mathrm{Z}_{\max }$ & $\odot$ \\
\hline \multirow{4}{*}{$B M 6438$} & $\mathrm{P}$ & 11.42 & 11.27 & 10.57 & 9.65 & 8.69 & 7.66 & 6.57 & 11.44 & 0.00 \\
\hline & $\mathrm{He}$ & 2.10 & 2.08 & 1.95 & 1.79 & 1.61 & 1.43 & 1.23 & 2.11 & 0.00 \\
\hline & Ho & 0.90 & 0.89 & 0.81 & 0.72 & 0.62 & 0.52 & 0.41 & 0.90 & 0.00 \\
\hline & all & 14.43 & 14.23 & 13.34 & 12.16 & 10.92 & 9.61 & 8.21 & 14.45 & 0.00 \\
\hline \multirow[t]{4}{*}{ SODIMicro2 } & $\mathbf{P}$ & 11.72 & 11.57 & 10.85 & 9.91 & 8.92 & 7.86 & 6.74 & 11.74 & 0.00 \\
\hline & $\mathrm{He}$ & 2.10 & 2.07 & 1.93 & 1.74 & 1.54 & 1.33 & 1.11 & 2.11 & 0.00 \\
\hline & Ho & 1.20 & 1.18 & 1.09 & 0.98 & 0.85 & 0.72 & 0.58 & 1.20 & 0.00 \\
\hline & all & 15.03 & 14.82 & 13.87 & 12.63 & 11.31 & 9.92 & 8.43 & 15.05 & 0.00 \\
\hline \multirow[t]{4}{*}{ BMS4015 } & $\mathrm{P}$ & -9.88 & -3.00 & 1.34 & 2.72 & 3.18 & 3.24 & 3.05 & 3.25 & 0.18 \\
\hline & $\mathrm{He}$ & 2.10 & 2.08 & 1.95 & 1.79 & 1.61 & 1.43 & 1.23 & 2.11 & 0.00 \\
\hline & Ho & -1.80 & -0.81 & -0.19 & 0.02 & 0.11 & 0.12 & 0.12 & 2.29 & 0.21 \\
\hline & all & -9.58 & -1.73 & 3.10 & 4.53 & 4.90 & 4.79 & 4.40 & 4.91 & 0.16 \\
\hline \multirow[t]{3}{*}{ BMS4017 } & $\mathrm{P}$ & -15.57 & -6.69 & -0.94 & 1.07 & 1.91 & 2.24 & 2.27 & 2.29 & 0.23 \\
\hline & $\mathrm{He}$ & 2.4 & 2.37 & 2.23 & 2.04 & 1.84 & 1.63 & 1.41 & 2.41 & 0.00 \\
\hline & all & -13.17 & -4.32 & 1.29 & 3.11 & 3.75 & 3.87 & 3.68 & 3.88 & 0.19 \\
\hline
\end{tabular}

From the data of all informative markers individual linkage phases of the proximal region of BTA1 were reconstructed which most likely harbour the polled mutation. The corresponding haplotype phases for each sire are given in Table 3. If the haplotype phases of the sire and the genotype of the offspring are known, the accuracy of the prediction of the polled status in the offspring depends mainly upon the individual genotype of the offspring, and the frequencies of the polled linked paternal alleles in the population. The inheritance of the horn status was clearly identified if one of the alleles of the offspring differed from the paternal alleles. In the case of heterozygous genotypes identical with the paternal ones, the maternal genotype was 
Table 3

Individual haplotypes harbouring most likely the polled mutation (Individuelle Haplotypen, die mit höchster Wahrscheinlichkeit die Mutation für Hornlosigkeit tragen)

\begin{tabular}{lllll}
\hline Sire & BM6438 & SOD1Micro2 & BMS4015 & BMS4017 \\
\hline $\mathrm{P}$ & 3 & 4 & 5 & 5 \\
$\mathrm{He}$ & 3 & 4 & 1 & 3 \\
$\mathrm{Ho}$ & 3 & 4 & 2 & not informative \\
\hline
\end{tabular}

used to decide which allele was inherited from the father. Offspring were excluded from the analyses, if their paternal alleles were not undoubtedly identified, e.g. in the case of identical heterozygous sire and dam genotypes.

Frequencies of the marker alleles in Simmental breed were detected by genotyping the horned dams of the offspring as a representative sample. Table 4 gives the allele frequencies of the tested markers. Marker alleles of the three sires which are in the same linkage phase with the polled mutation are marked in bold. These alleles are distributed at high or medium frequencies in the random sample of Simmental.

Table 4

Frequencies of marker alleles in the population (48 dams) (Markerallel-Frequenzen in der Population (48 Kühe))

\begin{tabular}{llllllll}
\hline & animals & \multicolumn{2}{c}{ Allele frequencies } & & & \\
Marker & $\mathrm{n}$ & 1 & 2 & 3 & 4 & 5 & 6 \\
\hline BM6438 & 49 & 0.19 & 0.08 & 0.23 & 0.50 & - & - \\
SODIMicro2 & 46 & 0.02 & 0.25 & 0.05 & $\mathbf{0 . 1 8}$ & 0.50 & - \\
BMS4015 & 56 & $\mathbf{0 . 1 2}$ & $\mathbf{0 . 1 6}$ & 0.65 & 0.02 & $\mathbf{0 . 0 4}$ & 0.01 \\
BMS4017 & 56 & 0.06 & 0.43 & $\mathbf{0 . 2 1}$ & 0.05 & $\mathbf{0 . 2 5}$ & - \\
\hline
\end{tabular}

Bold: alleles of sires, which are linked with the polled mutation

For marker assisted introgression of the polled mutation into a horned herd via sire selection the information content of the two tightly linked markers BM6438 and SODIMicro2 is highest. The haplotype of the sire harbouring the polled mutation is inherited with the probability $p_{r}=0.5\left(1-\theta_{1}\right)\left(1-\theta_{2}\right)$, with $\theta_{1}=$ recombination rate between the polled locus and marker $B M 6438, \theta_{2}=$ recombination rate between the polled locus and SODIMicro2. The accuracy of the prediction of horn formation in an offspring depends on the occurrence of recombinant non-mutated paternal haplotypes (favoured paternal marker haplotype, but without polled mutation) and the occurrence of the favoured paternal haplotype among the horned dams. The probability $p_{f}$ of recombinant non-mutated paternal haplotypes in the offspring despite the presence of the favoured paternal marker haplotype is $p_{f}=0.5 \theta_{1} \theta_{2}$. The probability $P_{M}$ of the occurrence of the favoured haplotype among the dams is $P_{M}=f_{1} f_{2}$, where $f_{1}$ denotes the frequency of the polled linked paternal allele of marker $B M 6438$, and $f_{2}$ the frequency of the polled linked paternal allele of marker SOD1Micro2. The probability $P_{C}$ of a correct selection decision for the presence of the polled mutation is $P_{C}=\frac{p_{r}}{\left(p_{r}+p_{f}\right)\left(1-P_{M}\right)+P_{M}}$. In our case with $\theta_{1}=\theta_{2}=0$ the equation simplifies to $P_{C}=1 /\left(1+P_{M}\right)$. The probability of correct selection decision is 0.96 in our population. 


\section{Conclusion}

From our pedigree study we can summarise the following conclusions: Identical marker alleles of BM6438 and SOD1Micro2 which are segregating with the polled mutation were identified for all three sires, even in the smallest pedigree comprising only five offspring. The identical linkage phases may be a hint of kinship. However, no relationship was found over the last six generations. The genotyping of offspring at marker loci BM6438 and SOD1Micro2 permits the detection of the favoured haplotype and thus, the differentiation between homozygous and heterozygous hornless animals. The accuracy of the prediction of the polled genotype is reduced by the probability of recombination between the paternal phases and the inheritance of randomly occurring favoured haplotype by the horned dam. Currently, this knowledge is appropriate for marker assisted introgression of the polled mutation into a horned herd with high precision.

\section{Acknowledgements}

We thank the breeders for support in collecting blood from polled and hornless animals.

\section{References}

BRENNEMAN, R.; DAVIS, S.; SANDERS, T.; TURNE, J.; TAYLOR, J.:

The polled locus maps to BTAI in a Bos indicus x Bos taurus cross. J. of Heredity 87 (1996), 156-61

GEORGES, M.; DRINKWATER, R.; KING, T.; MISHRA, A.; MOORE, S.S.; NIELSEN, D.; SARGEANT,

L.S.; SORENSEN, A.; STEELE, M.R.; ZHAO; X.; WOMACK, J.E.; HETZEL, J.:

Microsatellite mapping of a gene affecting horn development in Bos taurus. Nature Genetics 4 (1993), 206-10

HARLIZIUS, B.; TAMMEN, I.; EICHLER, K.; EGGEN, A.; HETZEL, D.J.:

New markers on bovine Chromosome 1 are closely linked to the polled gene in Simmental and Pinzgauer cattle. Mamm. Genome 8 (1997), 255-7.

KAPPES, S.M.; KEELE, J.W.; STONE, R.T.; MCGRAW, R.A.; SONSTEGARD, T.S.; SMITH, T.P.; LOPEZ-

CORRALES, N.L.; BEATTIE, C.W.:

A second-generation linkage map of the bovine genome. Genome Research 7 (1997), 235-49

KRÄUßLICH, H.; RÖHRMOSER, G.:

Breeding a line of Polled German Simmentals. Züchtungskunde, Stuttgart 67 (1995) 15-24

LONG, C.R.; GREGORY, K.E.:

Inheritance of the horned, scurred, and polled condition in cattle. J. of Heredity 69 (1978), 395-400

MARQUESS, F.L.S.; BRENNEMAN, R.A.; SCHMUTZ, S.M.; TAYLOR, J.F.; DAVIS, S.K.: A high polymorphic bovine dinucleotide repeat SODIMICRO2. Animal Genetics 28 (1997), 70

SCHMUTZ, S.M.; MARQUESS, F.L.; BERRYERE, T.G.; MOKER, J.S.: DNA marker-assisted selection of the polled condition in Charolais cattle. Mamm. Genome 6 (1995), 710-3

SONSTEGARD, T.S.; ABEL PONCE DE LEON, F.; BEATTIE, C.W.; KAPPES, S.M.:

A chromosome-specific microdissected library increases marker density on bovine chromosome 1. Genome Research 7 (1997), 76-80

TAYLOR, J.F.; EGGEN, A.; ALEYASIN, A.; ARMITAGE, S.M.; BARENDSE, W.; BEEVER, J.E.; BISHOP, M.D.; BRENNEMAN, R.A.; BURNS, B.M.; DAVIS, S.K.; ELO, K.; HARLIZIUS, B.; KAPPES, S.M.; KEELE, J.W.; KEMP, S.J.; KIRKPATRICK, B.W.; LEWIN, H.A.; MA, R.Z.; MCGRAW, R.A.; POMP, D.; STONE, R.T.; SUGIMOTO, Y.; TEALE, A.J.; VAIMAN, D.; VILKKI, J.; WILLIAMS, J.L.; YEH, C-C.; ZANOTTI, M.C.:

Report on the first workshop on the genetic map of bovine chromosome 1. Animal Genetics 28 (1998), 228-235 
Received: 1999-12-14

Accepted: 2000-04-10

Authors' addresses

Dr. GUDRUN A. BROCKMANN, Dr. FRIEDRICH TEUSCHER,

Prof. Dr. MANFRED SCHWERIN

Forschungsinstitut fur die Biologie landwirtschaftlicher Nutztiere

Wilhelm-Stahl-Allee 2

D-18196 Dummerstorf

Germany

E-Mail: brockman@fon-dummerstorf.de

Dr. JÖRG MARTIN

Institut für Tierproduktion Dummerstorf der Landesforschungsanstalt

für Landwirtschaft und Fischerei Mecklenburg-Vorpommern

Wilhelm-Stahl-Allee 2

D-18196 Dummerstorf

Germany 